\title{
NAÏVE JUVENILE DIAMONDBACK TERRAPINS: Kin Recognition in Controlled Encounter Experiments
}

NORTHERN DIAMONDBACK TERRAPIN (MALACLEMYS TERRAPIN) TURTLE HATCHLINGS RAISED AS PART OF A LABORATORY HEADSTARTING PROGRAM ARE THE FOCUS OF KIN RECOGNITION STUDIES TAKING PLACE AT BOSTON COLLEGE. EXPERIMENTS EXAMINED BASKING BEHAVIORS IN 13 TRIALS OF FAMILIAR KIN AND 11 TRIALS OF UNFAMILIAR NON-KIN. FAMILIAR KIN AVERAGED MORE AGGRESSIVE ENGAGEMENTS PER TRIAL (2.44 VS. 0.36), MORE DISPLACEMENTS PER TRIAL (13.36 VS. 3.91), AND MORE INSTANCES OF CLIMBING ON ONE ANOTHER (13.36 VS. 2.36). FAMILIAR KIN BASKED IN CONGREGATIONS MORE FREQUENTLY PER TRIAL THAN UNFAMILIAR NON-KIN. THESE DATA SUGGEST THAT DIAMONDBACK TERRAPINS TREAT EACH OTHER DIFFERENTLY BASED ON EITHER KINSHIP OR FAMILIARITY-OR BOTH. FURTHER RESEARCH WILL BE CONDUCTED ON FAMILIAR AND UNFAMILIAR KIN AND NON-KIN GROUPINGS TO HELP ELUCIDATE THE EXISTING DATA BY DETERMINING WHICH VARIABLE HAS GREATER CONSEQUENCE AND IF HAMILTON'S KIN SELECTION THEORY CAN BE APPLIED TO TERRAPIN JUVENILE SOCIAL BEHAVIOR. 


\section{INTRODUCTION}

Diamondback terrapins (Malaclemys terrapin) are a brackish species of water turtle, living in salt marshes, whose range includes most of the eastern seaboard of the United States, extending from Florida to Cape Cod, Massachusetts. Terrapins are ectotherms (i.e. cold-blooded) and thus must regulate their body temperature through their behaviors; one way of doing so is through basking. Basking sites, therefore, are a high value resource for terrapins and areas where terrapins may interact and potentially be in conflict.

The Boston College Diamondback terrapin headstarting project recovers nests that are highly vulnerable and unlikely to hatch from Sandy Neck Barrier Beach in Barnstable, Massachusetts on Cape Cod. Selected nests are incubated, the eggs hatched, and the hatchlings reared in a laboratory setting for a ten-month period. Terrapin hatchlings are then released into the saltmarsh in late spring of the following year. Studies conducted during headstarting periods aim to understand aspects of terrapin natural history that are important to increasing their survival rate. The first year of a terrapin's life is a critical period of physical, neurological, and social development. As such, raising Diamondback terrapins in a laboratory setting for the first ten months of their lives may impact their ability to cope with challenges in their natural environment once they have been released, including interactions with wild conspecifics (members of the same species).

Common observations have previously noted the social nature of Diamondback terrapins, suggesting the possibility that they form social groups and the potential that they distinguish siblings from non-siblings. Consequently, it is essential to ensure that headstarted Diamondback terrapins are raised in conditions that provide appropriate opportunities for both physical and social development. Social behaviors in terrapins may have crucial implications for their ability to interact, join social groups, and ultimately reproduce when released into their natural habitat. Basking sites, as limited resources in the wild, are common locations for conspecific interactions and aggregations in vari- ous turtle species and may prove integral to understanding the formation and characteristics of social groups.

Exchanges between individuals occur regularly on basking sites. Aggressive engagements have been documented in Pennsylvanian wood turtles in the form of nudging, ramming, and biting. Basking western pond turtles were documented biting and ramming one another as a method of displacement from basking sites. ${ }^{\text {ii }}$ Lizards have also been described as capable of exhibiting numerous social behaviors, both hostile and nonviolent. Crowded basking sites resulted in increased social behavior, increased aggression, and a switch to hierarchical behavior. ${ }^{\text {iii }}$ These documented behaviors serve as templates to inform our own observations on Diamondback terrapin social behaviors.

Kin recognition, one of many methods by which complex animals may form social groups, is the ability of an organism to distinguish between individuals of the same species based upon the degree of relatedness, and often involves preferential behaviors such as resource allocation. Hamilton's kin selection theory suggests that in kin groups, larger individuals will share a limited resource (in this case the basking site) with smaller individuals if they are related. This results in a lower variance in mean size and functions to preserve the genes of a family group. In contrast, non-kin groups, according to the theory, have a higher variance in size since larger individuals are less willing to share resources, and thus, act to preserve their individual genes. ${ }^{\text {iv }}$ Though undocumented in Diamondback terrapins, kin recognition has been established in related species such as the common toad, ${ }^{\mathrm{v}}$ wood frog tadpoles, ${ }^{\mathrm{vi}}$

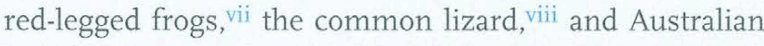
lizards. ix

\section{5-2006 METHODS}

\section{HUSBANDRY}

Diamondback terrapin eggs from nests designated to be headstarted were deposited under one to two inches of sand in small, individual cups labelled with each terrapin's nest information. These cups were placed in an incubator kept 
at 80 degrees F on a I2-hour light/dark cycle. Upon hatching, the eggs were removed from the incubator and placed in a headstarting tank, divided into seven partitions. False bottoms were used in headstarting tanks to keep water levels relatively low, a safety measure as the hatchlings developed their swimming abilities. In December of 2005, terrapin maturation allowed for terrapins to be divided into standard tank arrangements, in which partitions housed and separated four terrapins.

Terrapins were divided into groups of either four siblings or four non-siblings. Ideally, one would have equal groups of familiar kin (kin living together since birth) and familiar non-kin (non-kin living together since birth). Such distribution would also allow for the testing of unfamiliar kin groups and unfamiliar non-kin groups. However, due to the allotted number of headstarted terrapins, the 2005 2006 study only tested groups of familiar kin and unfamiliar non-kin.

Terrapins were all fed the same diet of nutrient pellets for 45 minutes daily and were always fed before the start of an experimental trial. Their identical diets and consistent dietary schedules may be used to eliminate dietary variables as a basis for kin recognition or any other behavioral patterns observed in Diamondback terrapins.

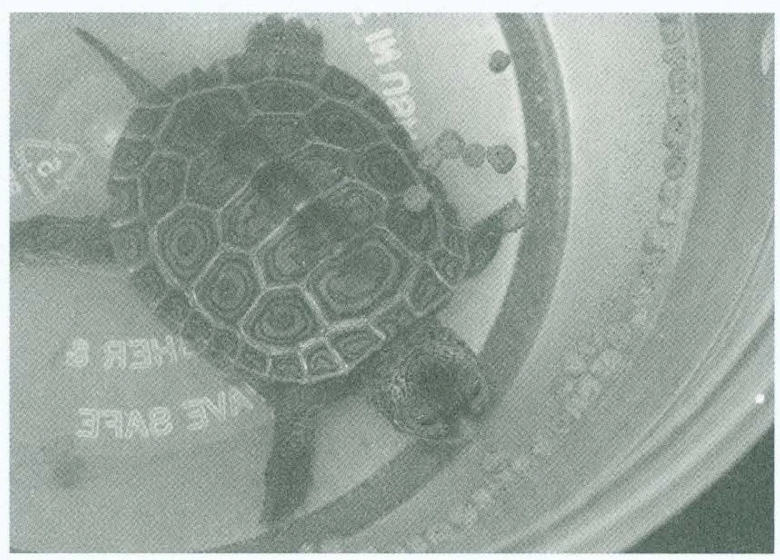

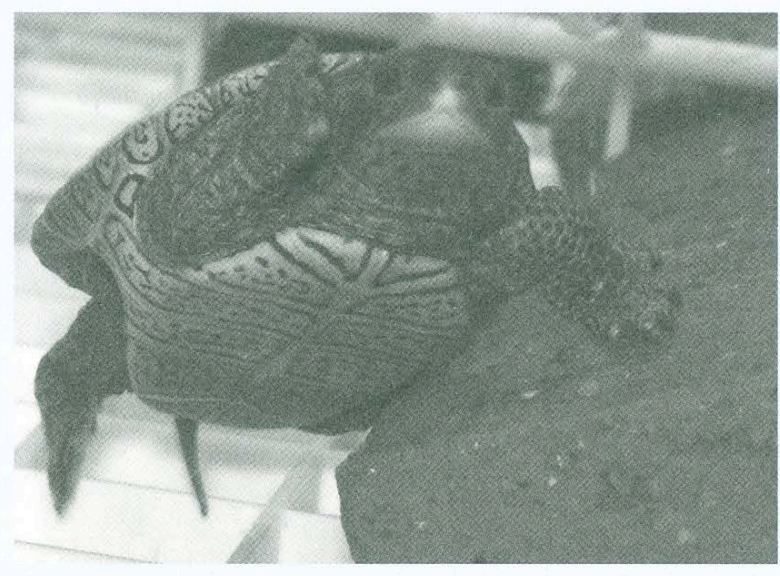

\section{EXPERIMENTAL TRIALS}

An experimental tank featured a single brick ramp leading to a single brick basking site, located on the far side of the tank, opposite the filter. A heat lamp was placed directly above the basking site, making it the most intensely lit and heated area in the tank. The basking site's small size and focused lighting were set up in a manner that would prove conducive to studying behavior surrounding a limited basking site. This could stimulate competition and subsequent aggression, characteristics that have been shown to vary among kin and non-kin in species exhibiting kin recognition. Terrapins within either kin or non-kin groups were placed in the tank and videotaped for ninety minutes. The first thirty minutes served as an acclimation period, while the last sixty minutes represented the "testing time." During testing, human presence was kept to a minimum in order to prevent terrapin reactions or altered behaviors which may result from human observers.

Trials were scored for four behaviors (aggression, climbing, displacement, and basking congregations) and additional qualitative observations were noted. This study sought to describe and measure the behavior of collective groups, not individual animals; hence, individual identity during experimental trials was not tracked, aside from the confirmation that the proper individuals of a group were being tested. All scored behaviors took place on the basking site. Biting was viewed purely as an aggressive behavior and was 
scored as such. Climbing on the backs of other turtles was viewed primarily as a mark of accepted, tolerated physical contact, and therefore indicative of a level of social comfort in the animals. Displacement was measured as a marker of basking site activity; it can take the form of aggression when a turtle is displaced due to biting, ramming, or otherwise influenced to leave the basking site by another turtle's visual contact or body posture. However, displacement can also be a result of a crowded basking site where turtles are forced off due to a lack of space, or due to falling off the back of another turtle while climbing on top of it. Thus, displacement cannot be viewed as a direct measure of aggression, but rather as a reasonable measure for the level of interactions taking place on the basking site. Basking congregations constituted the number of instances, in a given trial, in which there were one, two, three, or four terrapins on the basking site simultaneously. Several additional behaviors were noted: lunging, chasing, and posturing.

The final data analysis was based upon I3 trials of familiar kin and II trials of unfamiliar non-kin. For the behaviors of biting, displacement, and climbing, t-tests were run on each individual behavior to compare the differences between familiar kin and unfamiliar non-kin samples. Behaviors were analyzed seperately because they were not mutually exclusive. For example, the scenario of one terrapin biting another may additionally induce a displacement of the attacked turtle. Using a t-test avoided the possibility of counting a behavior multiple times due to such behavioral causality. Significance was established at $\mathrm{P}<0.05$. Basking congregations were analyzed using a one-way ANOVA to measure for differences between kin and nonkin. Again, significance was established at $\mathrm{P}<0.05$.

\section{5-2006 RESULTS}

Raw data for all analyzed kin and non-kin behavior may be seen in Table $\mathrm{I}$, Table 2, Table 3, and Table 4.

Familiar kin groups averaged 2.44 instances of biting per trial, significantly more than unfamiliar non-kin groups, which averaged 0.36 bites per trial $(\mathrm{P}=0.04)$. There were
13.36 displacements per trial in familiar kin and 3.9I in unfamiliar non-kin; this difference was significant with $\mathrm{P}=$ 0.0009 . Instances of climbing were also significantly different between the groups, with I3.36 per trial in familiar kin and 2.36 in unfamiliar non-kin, $\mathrm{P}=0.005$. This data can also be found in Table 5 and Chart I.

The results of running a one-way ANOVA for basking congregations in familiar kin and unfamiliar non-kin can be found in Table 6 and in a condensed version in Table 7 , also accompanied by Chart 2 . Instances of a lone turtle occupying the basking site occured an average of Io.46 times per trial in familiar kin, versus II.73 times per trial in unfamiliar non-kin. This difference was not significant $(\mathrm{P}=$ 0.684). Congregations of two turtles occurred an average of 20.62 times per trial in familiar kin, significantly more than the average of 7.82 occurrences in unfamiliar non-kin, $\mathrm{P}=0.007$. There were significantly more congregations of three turtles in familiar kin, I5.23 per trial, than in unfamiliar non-kin, 2.09 per trial $(\mathrm{P}=0.003)$. Finally, familiar kin basked in congregations of four 4.3I times per trial, while unfamiliar non-kin averaged o.I8 times per trial, a significant difference $(\mathrm{P}=0.015)$.

\section{5-2006 DISCUSSION}

Familiar kin basked significantly more than unfamiliar non-kin at all congregation levels, except when there was a lone turtle on the basking site and subsequently no significant difference. This study did not examine unfamiliar kin and familiar non-kin groups, thus responsibility for this discrepancy cannot be reduced to familiarity or kinship alone. Accounting for these two additional groups in a future study would allow one to determine the variable responsible for increased basking. The basking data found in this study indicates variability in the way terrapins from different groups behave towards each other. This is possibly indicative of a certain level of social comfort between the two types of groups. Terrapins may bask in increased levels with familiar kin because there may be an established social hierarchy, or familiarity/kinship may afford individuals of social groups a certain level of security in basking in 
TABLE 1: BITING, DISPLACEMENT, AND CLIMBINC RESULTS FROM FAMILIAR KIN TRIALS

\begin{tabular}{lllll|}
\hline & & & & \\
DATE & GROUP & BITING & DISPLACEMENT & CLIMBING \\
$1 / 19 / 06$ & 16 & 3 & 7 & 12 \\
$1 / 22 / 06$ & 16 & 4 & 8 & 11 \\
$1 / 24 / 06$ & 16 & 5 & 11 & 16 \\
$1 / 26 / 06$ & 16 & 6 & 16 & 13 \\
$2 / 1 / 06$ & 16 & 4 & 21 & 21 \\
$2 / 7 / 06$ & 16 & 2 & 6 & 3 \\
$2 / 14 / 06$ & 3 & 3 & 53 & 51 \\
$2 / 15 / 06$ & 4 & 0 & 16 & 19 \\
$2 / 24 / 06$ & 3 & 7 & 14 & 12 \\
$3 / 20 / 06$ & 3 & 2 & 6 & 0 \\
$3 / 21 / 06$ & 4 & 1 & 13 & 12 \\
$3 / 29 / 06$ & 4 & 0 & 2 & 4 \\
$3 / 31 / 06$ & 3 & 0 & 0 & 0 \\
& & & &
\end{tabular}

TABLE 2: BITING, DISPLACEMENT, AND CLIMBING RESULTS FROM UNFAMILIAR NON-KIN TRIALS

$\begin{array}{lccccc}\text { DATE } & \text { GROUP } & \text { BITINC DISPLACEMENT CLIMBINC } & \\ 1 / 30 / 06 & 1 & 0 & 5 & 2 & 0 \\ 1 / 31 / 06 & 2 & 0 & 6 & 9 & 97 \\ 2 / 2 / 06 & 1 & 1 & 9 & 4 & 97 \\ 3 / 1 / 06 & 6 & 1 & 7 & 6 & 0 \\ 3 / 23 / 06 & 7 & 1 & 4 & 1 & \\ 3 / 24 / 06 & 8 & 0 & 0 & 0 & 1 \\ 3 / 28 / 06 & 9 & 1 & 2 & 2 \\ 4 / 3 / 06 & 10 & 0 & 9 & 0 \\ 4 / 4 / 06 & 11 & 0 & 0 & 1 \\ 4 / 6 / 06 & 12 & 0 & 0 & 0 \\ 4 / 11 / 06 & 13 & 0 & 1 & 1\end{array}$

TABLE 3: BASKING CONGREGATION RESULTS FROM FAMILIAR KIN TRIALS

\begin{tabular}{|c|c|c|c|c|c|}
\hline \multirow{4}{*}{ DATE } & \multirow{4}{*}{ GROUP } & \multirow{2}{*}{\multicolumn{4}{|c|}{$\begin{array}{l}\text { NUMBER OF INSTANCES OF } \\
\text { TURTLE CONGREGATIONS }\end{array}$}} \\
\hline & & & & & \\
\hline & & ONE & TWO & THREE & FOUR \\
\hline & & TURTLE & TURTLES & TURTLES & TURTLES \\
\hline $1 / 19 / 06$ & 16 & 4 & 19 & 16 & 4 \\
\hline $1 / 22 / 06$ & 16 & 21 & 33 & 15 & 1 \\
\hline $1 / 24 / 06$ & 16 & 15 & 24 & 19 & 5 \\
\hline $1 / 26 / 06$ & 16 & 10 & 28 & 25 & 5 \\
\hline $2 / 1 / 06$ & 16 & 22 & 44 & 29 & 6 \\
\hline $2 / 7 / 06$ & 16 & 13 & 13 & 3 & 0 \\
\hline $3 / 29 / 06$ & 4 & 5 & 8 & 2 & 0 \\
\hline $3 / 31 / 06$ & 3 & 0 & 0 & 0 & 0 \\
\hline $2 / 74 / 06$ & 3 & 10 & 35 & 45 & 19 \\
\hline $2 / 15 / 06$ & 4 & 4 & 12 & 15 & 6 \\
\hline $3 / 20 / 06$ & 3 & 13 & 12 & 1 & 0 \\
\hline $2 / 24 / 06$ & 3 & 6 & 15 & 13 & 7 \\
\hline $3 / 21 / 06$ & 4 & 13 & 25 & 15 & 3 \\
\hline
\end{tabular}

TABLE 4: BASKING CONGREGATION RESULTS FROM UNFAMILIAR NON-KIN TRIALS

\begin{tabular}{|c|c|c|c|c|c|}
\hline \multirow{4}{*}{ DATE } & \multirow{4}{*}{ GROUP } & \multicolumn{4}{|c|}{ NUMBER OF INSTANCES OF } \\
\hline & & \multicolumn{4}{|c|}{ TURTLE CONGREGATIONS } \\
\hline & & ONE & TWO & THREE & FOUR \\
\hline & & TURTLE & TURTLES & TURTLES & TURTLES \\
\hline $1 / 30 / 06$ & 16 & 4 & 19 & 16 & 4 \\
\hline $1 / 31 / 06$ & 16 & 21 & 33 & 15 & 1 \\
\hline $2 / 2 / 06$ & 16 & 15 & 24 & 19 & 5 \\
\hline $4 / 3 / 06$ & 16 & 10 & 28 & 25 & 5 \\
\hline $4 / 4 / 06$ & 16 & 22 & 44 & 29 & 6 \\
\hline $4 / 6 / 06$ & 16 & 13 & 13 & 3 & 0 \\
\hline $4 / 11 / 06$ & 4 & 5 & 8 & 2 & 0 \\
\hline $3 / 24 / 06$ & 3 & 0 & 0 & 0 & 0 \\
\hline $3 / 28 / 06$ & 3 & 10 & 35 & 45 & 19 \\
\hline $3 / 1 / 06$ & 4 & 4 & 12 & 15 & 6 \\
\hline $3 / 23 / 06$ & 3 & 13 & 12 & 1 & 0 \\
\hline
\end{tabular}


TABLE 5: T-TESTS FOR BITING, DISPLACEMENT, AND CLIMBING

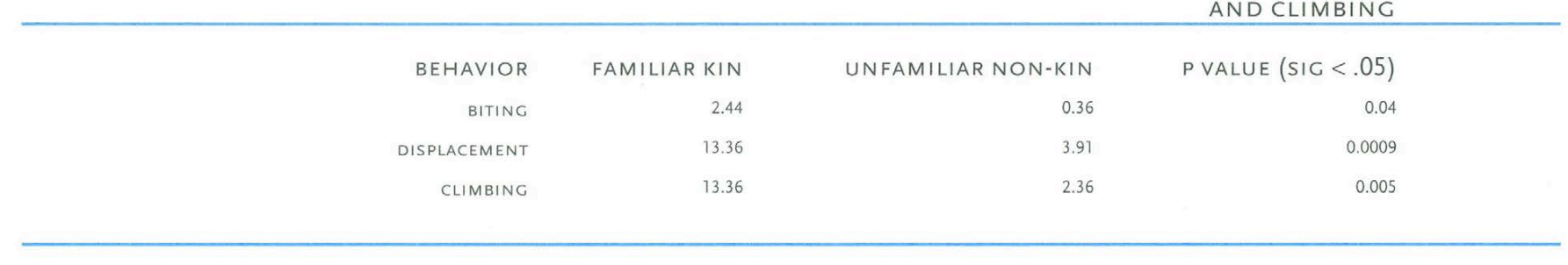

TABLE 6: ONE-WAY ANOVA FOR BASKING CONGREGATIONS

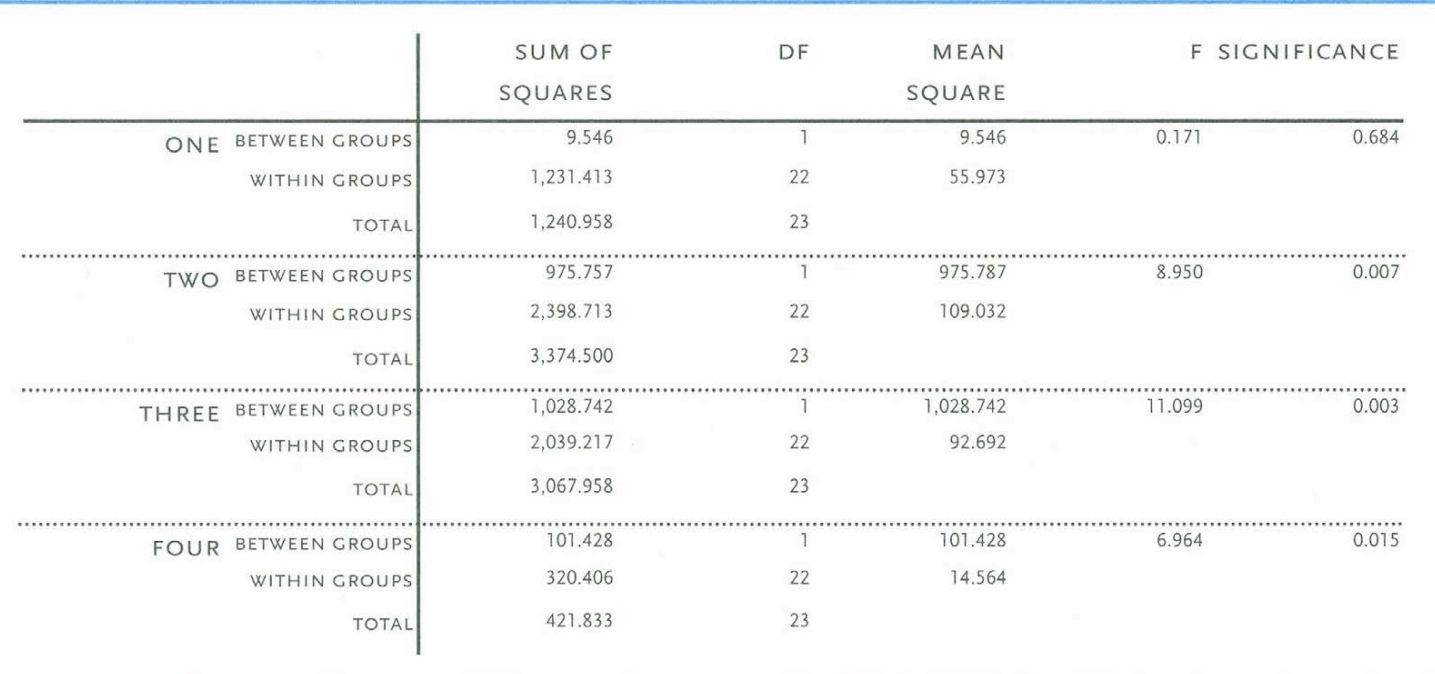

TABLE 7: CONDENSED BASKING CONGREGATION RESULTS

\begin{tabular}{|c|c|c|c|}
\hline CONGREGATIONS & FAMILIAR KIN & UNFAMILIAR NON-KIN & P VALUE $(S I G<.05)$ \\
\hline ONE TURTLE & 10.46 & 11.73 & 0.684 \\
\hline TWO TURTLES & 20.62 & 7.82 & 0.007 \\
\hline THREE TURTLES & 15.23 & 2.09 & 0.003 \\
\hline FOUR TURTLES & 4.31 & 0.18 & 0.015 \\
\hline
\end{tabular}




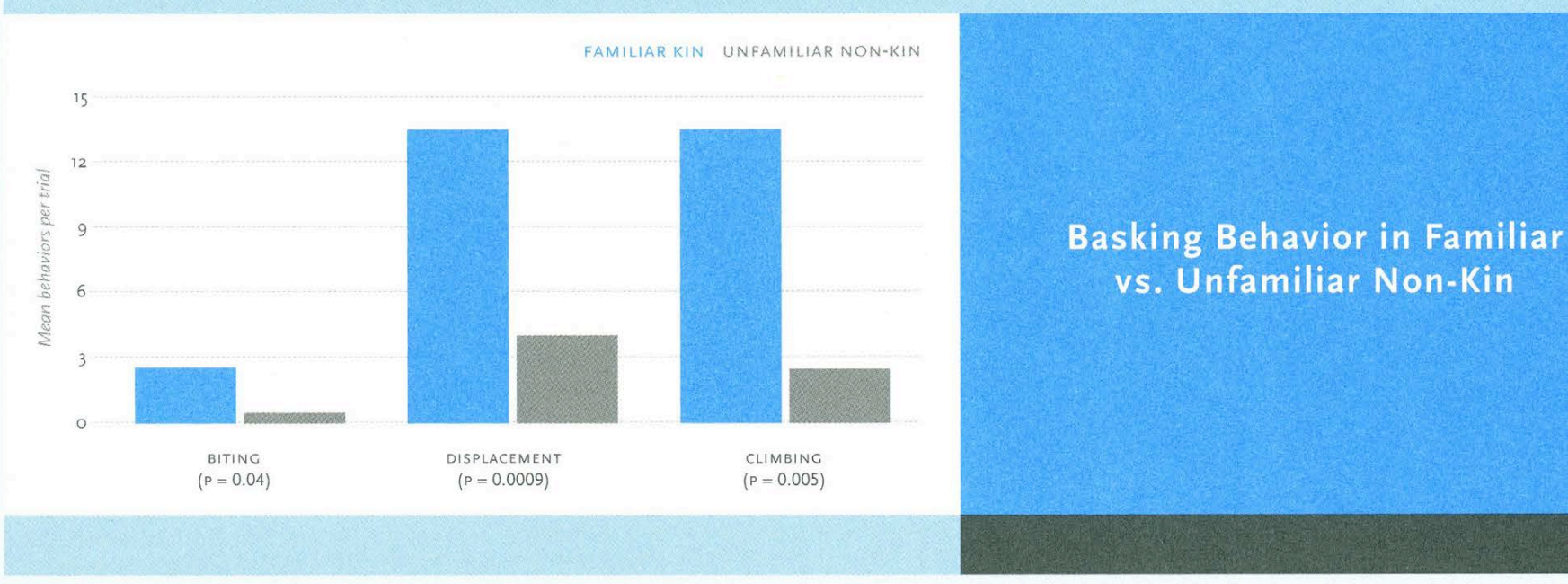

congregations with other terrapins. A reduced risk of aggression may exist if an individual is known to be a nonthreat by members of the same social group.

Familiar kin behaved more aggressively towards one another than unfamiliar non-kin, as can be seen by the significantly different levels of biting between the two groups. Aggression may occur as a function of increased basking, as seen in lizards. ${ }^{x}$ That is, biting may be a normal component of basking congregations; since familiar kin basked in greater congregations, this behavior would predict greater amounts of biting.

An additional consideration may be that familiar kin are more aggressive because they have a better understanding of what retaliation may ensue from the other turtle. Aggression may be a tool by which members of a social group can be reprimanded to their place within the social hierarchy, or dislodged momentarily so as to allow a higher ranking individual to occupy a preferable basking location. This was seen several times in the course of this study: a terrapin was ousted by an approaching group member and forced to bask in a new location, often one that was partially submerged, and thus, less preferable. Terrapins may not be as willing to risk biting other unfamiliar non-siblings if they are not able to anticipate what reaction will follow, i.e., whether a bitten terrapin will respond with extensive violence. This scenario creates a heightened risk, and thus it may be advantageous to avoid direct aggression altogether. Alternative methods of aggression should be considered in future studies.

The increased levels of displacement seen in familiar kin may also be a consequence of increased basking, or are otherwise indicative of increased interaction between turtles on the basking site. Displacement resulted from various behaviors: biting, posturing, climbing, and crowding. It will be imperative to categorize how many of each type of displacement occurs in future studies to determine the role of each displacement behavior.

There are also other important considerations for future protocols. Terrapins designated for familiar non-kin groups need to be placed in those groups immediately upon birth. It is unknown whether there exists a critical period in terrapins, during which lasting bonds might be formed if kin recognition does occur. Therefore, familiarity is ambiguous unless one eliminates the variability that would result from the possibility of a critical period early in life. 
Further investigation also needs to be made into how terrapin basking behaviors change over the course of the headstarting period. A steady testing of several groups during headstarting will ensure that any potential changes over the course of development may be attributed to actual developmental changes and not simply to a characteristic of the specific groups. Understanding how, why, and across what time period terrapins form social groups would be an asset to the Diamondback terrapin headstarting program. This program seeks to speed the terrapins' physical maturation without compromising their mental development. It is, therefore, especially important that they be able to develop any potential social tools critical to their ability to form and/or enter social groups in the wild, and eventually reproduce.

This study suggests that Diamondback terrapins behave differently towards one another based either on familiarity or kinship, with a higher tendency to bask, bite, climb, and otherwise actively interact with one another on a limited basking site. Such differential activity is not meant to suggest that terrapins should only be raised with and exposed to familiar kin. Isolating terrapins from non-kin could prove damaging in their ability to cope with unfamiliars and non-kin in the wild. The potential for kin recognition and the formation of social groups are sophisticated and complicated biological constructs. Future research should be given the opportunity to strengthen our understanding of these concepts and their role in Diamondback terrapins before any changes are made to headstarting protocols.

\section{FURTHER STUDY 2006-2007}

Research will be continued in 2006 and 2007 to expand upon the 2005-2006 study. Hatchlings from four nests will be divided into groups of kin and non-kin in order to run trials on both familiar and unfamiliar kin and non-kin. Behaviors will be scored employing the same methodology as described above. Collected information may provide explanatory support for the observed differences above. Furthermore, the results of this study may provide a greater understanding of how wild terrapins form social groups and share resources-key factors in their survival and recovery.

\section{ENDNOTES}

i. Kaufman (1992)

ii. Bury \& Wolfheim (I973)

iii. Brattstrom (I974)

iv. Hamilton (1964)

v. Saidapur \& Girish (2000)

vi. Waldman (I984)
Basking Congregations

in Familiar Kin vs. Unfamiliar Non-Kin

FAMILIAR KIN UNFAMILIAR NON-KIN

25

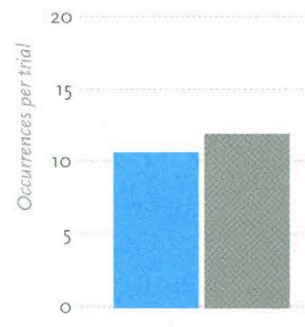

ONE

$(p=0.684)$

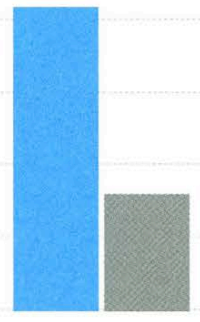

Two $(p=0.007)$

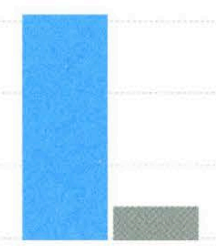

THREE $(P=0.003)$

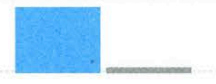

FOUR $(P=0.015)$ 


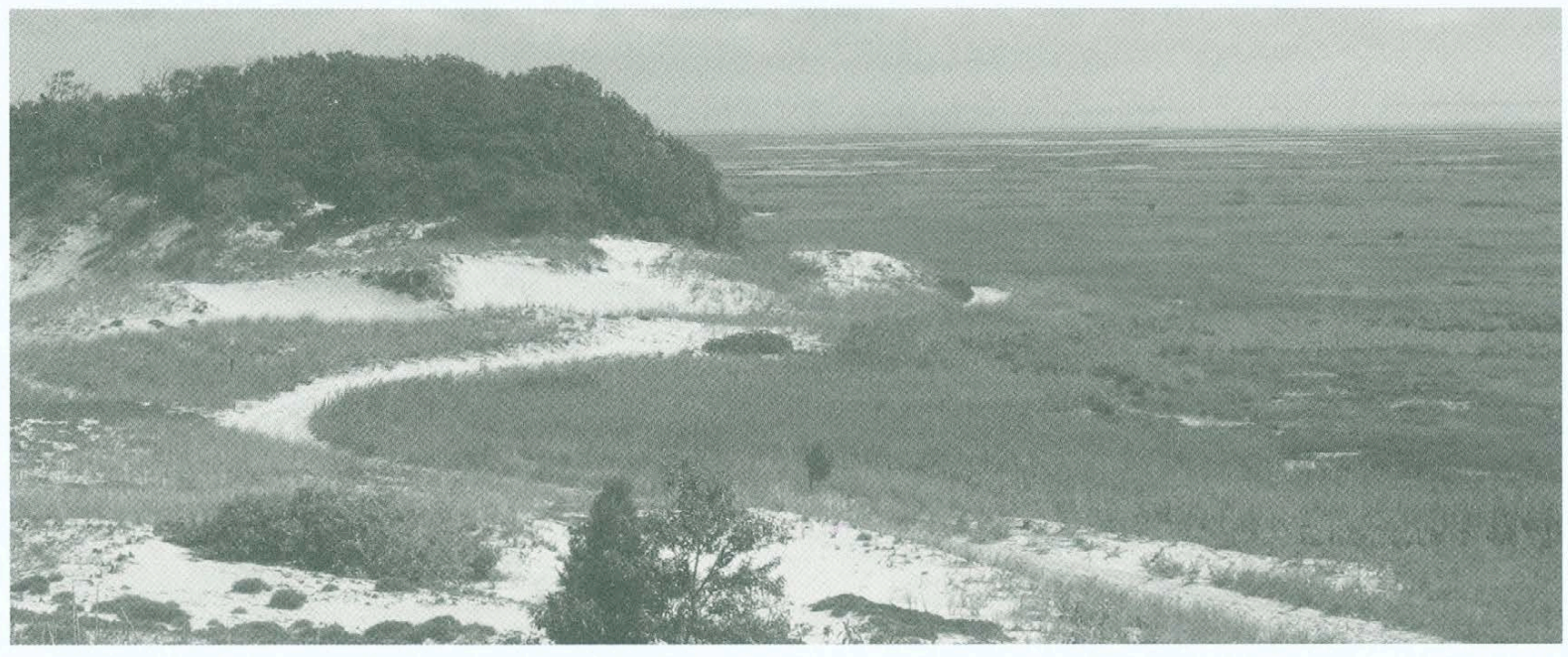

vii. Blaustein, et al. (I993)

viii. Lena \& Fraipoint (1998)

ix. Bull, et al. (200I)

x. Brattstrom (I974)

\section{REFERENCES}

Blaustein, Andrew R.; Yoshikawa, Tomoko; Asoh, Kazue; Walls, Susan C. I993. "Ontogenic shifts in tadpole kin recognition: loss of signal and pereception." Animal Behaviour, $46(3)$, pp. 525-538, September.

Brattstrom, Bayard H. I974. "The evolution of reptilian social behavior." American Zoologist, I4(I), pp. 35-49, March.

Bull, Michael C.; Griffin, Clare L.; Bonnett, Matthew; Gardner, Michael G.; Cooper, Stephen J. 200I. "Discrimination between related and unrelated individuals in the Australian lizard Egernia striolata." Behavioral Ecology and Sociobiology, 50(2), pp. I73-I79, July.

Bury, R. Bruce; Wolfheim, Jaclyn H. 1973. "Aggression in FreeLiving Pond Turtles (Clemmys Marmorata)" Bioscience 23(II), pp 659-662, November.

Hamilton, William D. I964. "The Genetical Theory of Social Behavior I and II." Journal of Theoretical Biology, 7, pp. I-52, July.

Kaufman, John H. r992. "The Social Behavior of Wood Turtles, Clemmys insculpta, in Central Pennsylvania." Herpetological Monographs, 6, pp. I-25, March.
Lena, Jean P.; Fraipont. Michelle. I998. "Kin recognition in the common lizard.” Behavioral Ecology and Sociobiology, 42(5), pp. 341-347, May.

Saidapur, Srinivas K.; Girish, S. 2000. "The ontogeny of kin recognition in tadpoles of the toad Bufo melanostictus." Journal of Bioscience, 25, pp. $267-273$, September.

Waldman, Bruce. I984. "Kin recognition and sibling association among wood frog (Rana sylvatica) tadpoles." Behavioral Ecology and Sociobiology, 14, pp. 71-180, June. 